УДК 524.8

O. Sergijenko, PhD,

Astronomical Observatory of Taras Shevchenko National University of Kyiv

\title{
DIPOLE OF THE LUMINOSITY DISTANCE AS A TEST FOR DARK ENERGY MODELS
}

The dependence of Hubble parameter on redshift can be determined directly from the dipole of luminosity distance to Supernovae la. We investigate the possibility of using the data on dipole of the luminosity distance obtained from the Supernovae la compilations SDSS, Union2.1, JLA and Pantheon to distinguish the dark energy models.

Key words: dark energy, Supernovae la, cosmological parameters

Introduction. According to the Planck data the dark energy in current epoch is close to the cosmological constant. This makes it much harder to detect the temporal variation of the dark energy equation of state parameter and to distinguish the dark energy models. The reliability of $w(z)$ determination will be significantly higher if the dependence $H(z)$ is measured directly instead of (or along with) the luminosity or angular diameter distances since taking numerical derivatives from the current observational data leads to the inaccurate results. Recent interest to testing the isotropy of the Supernovae la magnitude-redshift relation [1, 2] brings attention to the dipole of luminosity distance as a possible direct measure of the Hubble parameter [3]. In this paper we make an attempt to re-estimate the potential of the luminosity distance dipole to discriminate the dark energy models using current data on Supernovae la.

Dipole of the luminosity distance. According to [3,4] the first-order expansion of directional dependence of the luminosity distance reads:

where the monopole is

$$
d_{L}(z, \mathbf{n})=d_{L}{ }^{(0)}(z)+d_{L}{ }^{(1)}(z)(\mathbf{n} \cdot e)
$$

$$
d L(0)(z)=(1+z) \int 0 z d z^{\prime} / H\left(z^{\prime}\right)
$$

and the dipole is

$$
d L(1)(z)=|v 0|(1+z) 2 / H(z) \text {. }
$$

The variance of dipole

$$
(\Delta d L(1)(z)) 2=3(\ln (10) / 5) 2 \Delta m 2(d L(0)(z)) 2
$$

leads to the following estimate for precision of the $H(z)$ determination [3]:

$$
\Delta H(z) / H(z)=[\ln (10) 31 / 2 /(5|v 0|)][d L(0)(z) H(z) /(1+z) 2] \Delta m .
$$

Note that, according to [3], the uniform sky coverage by the Supernovae la survey is not necessary for using the luminosity distance dipole as a cosmological test. The properties of a possible survey designed for such a test are discussed in [3].

Model and data. As the dark energy model we use the minimally coupled classical scalar field with the equation of state parameter obtained from the condition $C_{a}{ }^{2}=p{ }^{*}{ }_{d e} / \rho^{*}{ }_{d e}=$ const [5]:

$$
w(a)=p_{d e} / \rho_{d e}=\left(1+c_{a}^{2}\right)\left(1+w_{0}\right) /\left(1+w_{0}-\left(w_{0}-c_{a}^{2}\right) \exp \left(3\left(1+c_{a}^{2}\right) \ln (a)\right)\right)-1 .
$$

We investigate 2 cases: distinguishing between the best-fit quintessential and phantom models with the parameters obtained from the same dataset (as it was done in [5,6]) and distinguishing the mean model from the model with all parameters at $1 \sigma$ or $2 \sigma$ confidence limits (in the manner of [7]).

The cosmological parameters and their confidence ranges are obtained by the Monte Carlo Markov chain (MCMC) [8] method implemented in the CosmoMC code (http://cosmologist.info/cosmomc). We assume the spatial flatness of the Universe.

In the first case we use the best-fit parameters (Table 1) estimated in [5] from the following datasets:

1. $C M B$ temperature fluctuations and polarization angular power spectra from the 7-year WMAP data (WMAP7)[9-11];

2. Baryon acoustic oscillations from SDSS DR7 (BAO) [12];

3. Hubble constant measurements from HST (HST) [13];

4. Big Bang Nucleosynthesis prior on the baryon abundance (BBN) $[14,15]$;

5. Supernovae la from SDSS compilation (SN SDSS) [16] (SALT2 [17] and MLCS2k2 [18] light curve fittings).

Table 1

The best-fit values of cosmological parameters for the models with quintessential (QSF) and phantom (PSF) scalar fields determined from 2 observational datasets: WMAP7+HST+BBN+BAO+SN SDSS SALT2 $\left(q_{1}, p_{1}\right)$ and WMAP7+HST+BBN+BAO+SN SDSS MLCS2k2 $\left(q_{2}, p_{2}\right)$ (from [5])

\begin{tabular}{|c|c|c|c|c|}
\hline Parameters & QSF, SALT2 $\left(\boldsymbol{q}_{\mathbf{1}}\right)$ & PSF, SALT2 $\left(\boldsymbol{p}_{\mathbf{1}}\right)$ & QSF, MLCS2k2 $\left(\boldsymbol{q}_{\mathbf{2}}\right)$ & PSF, MLCS2k2 $\left(\boldsymbol{p}_{\mathbf{2}}\right)$ \\
\hline$\Omega_{d e}$ & 0.730 & 0.723 & 0.702 & 0.692 \\
\hline$w_{0}$ & -0.996 & -1.043 & -0.830 & -1.002 \\
\hline$c_{a}^{2}$ & -0.022 & -1.120 & -0.880 & -1.190 \\
\hline $10 \Omega_{b} h^{2}$ & 0.226 & 0.223 & 0.226 & 0.223 \\
\hline$\Omega_{c d m} h^{2}$ & 0.110 & 0.115 & 0.108 & 0.119 \\
\hline$H_{0}$ & 70.2 & 70.4 & 66.3 & 67.8 \\
\hline
\end{tabular}

In the second case we determine the mean values of cosmological parameters and their confidence ranges (Table 2) from the combined dataset including:

- CMB TT, TE, EE angular power spectra and lensing from Planck [19];

- B-mode polarization for 2 frequency channels from BICEP2/Keck Array (BK) [20]; 
- $\quad$ power spectrum of galaxies from WiggleZ Dark Energy Survey [21];

- Supernovae la from JLA compilation [22];

- Hubble constant determination [23].

Here we apply flat priors with ranges of values [-2,-0.33] for wo and $[-2,0]$ for $\mathrm{Ca}^{2}$, so the dark energy model involves both quintessence and phantom subclasses.

The mean values, $1 \sigma$ and $2 \sigma$ confidence limits for cosmological parameters obtained from the observational dataset Planck2015+WiggleZ+SN JLA+BK

\begin{tabular}{|c|c|}
\hline Parameters & mean $\pm \mathbf{1} \boldsymbol{\sigma} \pm \mathbf{2} \boldsymbol{\sigma}$ \\
\hline$\Omega_{d e}$ & $0.691_{-0.012^{+0.012}}{ }_{-0.024}{ }^{+0.022}$ \\
\hline$w_{0}$ & $-1.024_{-0.058}{ }^{+0.062}{ }_{-0.125}{ }^{+0.120}$ \\
\hline$c_{a}{ }^{2}$ & $-1.460_{-0.540^{+0.145}}{ }_{-0.540^{+0.781}}$ \\
\hline $10 \Omega_{b} h^{2}$ & $0.222_{-0.002}{ }^{+0.002}{ }_{-0.00{ }^{+0.003}}$ \\
\hline$\Omega_{c d m} h^{2}$ & $0.119_{-0.001}{ }^{+0.001}{ }_{-0.003}{ }^{+0.003}$ \\
\hline$H_{0}$ & $67.9_{-1.2^{+1.2}}{ }_{-2.3}{ }^{+2.4}$ \\
\hline
\end{tabular}

For estimates based on the luminosity distance dipole we use the following Supernovae la compilations:

1. SDSS [16]: $288 \mathrm{SNe}$ (MLCS2k2, SALT2 light curve fitters): only statistical uncertainties;

2. Union2.1 [24]: $580 \mathrm{SNe}$ (SALT2): both statistical and systematic uncertainties;

3. JLA [22]: 740 SNe (SALT2): both statistical and systematic uncertainties;

4. Pantheon [25]: 1048 SNe (SALT2): both statistical and systematic uncertainties.

We assume $v_{0}=369.0 \mathrm{~km} / \mathrm{s}$ (from the CMB dipole which is due to the same motion) [26].

Results and discussion. In the left panels of Fig. 1-4 we present the calculated quantities $\Delta H_{\text {model }}(z) / H^{2}(z)$ and compare them with the corresponding quantities $\Delta H(z) / H^{2}(z)$ obtained from the luminosity distance dipole using the data from Supernovae compilations in 16 redshift bins with the width $0.1(0<z<1.6)$. In the right panels we estimate the number of Supernovae that is needed to distinguish between the models from the left panels.

From Fig. 1-4 it is clear that distinguishing between the best-fit models and between the mean model and the model with all parameters at $1 \sigma$ limits is not realistic at all. The number of Supernovae necessary to distinguish the model with mean parameters from the model with all parameters at the limits of their $2 \sigma$ confidence ranges is minimal in the first redshift bin $(0<z<0.1)$. For SN SDSS with MLCS2k2 fitting it is 1998 or 4063, for SN SDSS with SALT2 fitting 2735 or 5563 , for SN Union2.14466 or 9083, for SN JLA 5411 or 11006, for SN Pantheon C11 3074 or 6252 and for SN Pantheon G10 3040 or 6183 for the upper or lower limits correspondingly. For higher redshift bins the needed numbers of Supernovae are larger at least by one order of magnitude.

Conclusion. We have found that despite the major increase in number of Supernovae in available compilations over the last 12 years the current prospects of using the dipole of luminosity distance for distinguishing the dark energy models are not bright. This is partly due to the fact that the uncertainties in determination of the cosmological parameters from other data are now much smaller and the tests for dark energy equation of state parameter should be more precise. Another reason is that now taken into account systematic errors result in the larger total ones. So, to make the luminosity distance dipole useful as the cosmological test it is necessary not only to increase largely the number of Supernovae (especially the low-redshift ones) in a dataset, but also to reduce the uncertainties of distance moduli by improving the light curve fitting and to control better the systematics.
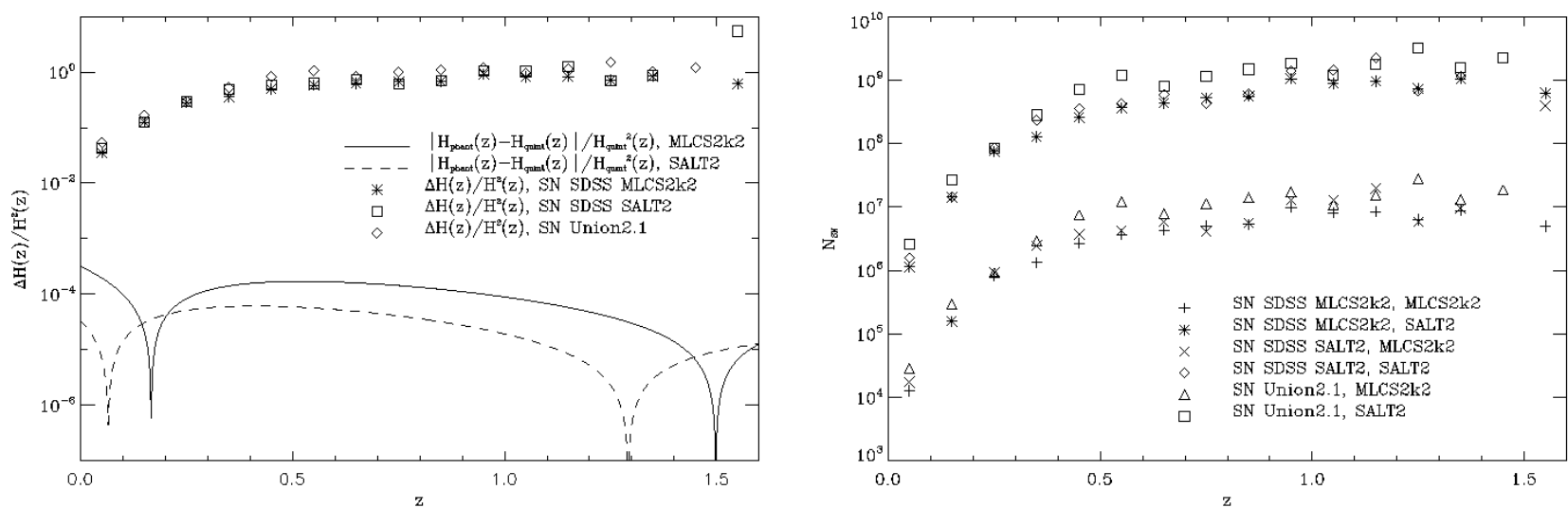

Fig. 1. Left: the theoretical relative differences $\Delta H_{\text {model }}(z) / H^{2}(z) \equiv\left|H_{\text {phant }}(z)-H_{\text {quint }}(z)\right| / H_{\text {quint }}{ }^{2}(z)$ compared to $\Delta H(z) / H^{2}(z)$ from Supernovae compilations. Right: the minimal number of Supernovae that is necessary for distinguishing the models in left panel if the uncertainties of Supernovae magnitudes are the same as in the compilation from legend. After a comma we quote the data (type of Supernovae light curve fitting) used to estimate the best-fit parameters for the pair of compared models 

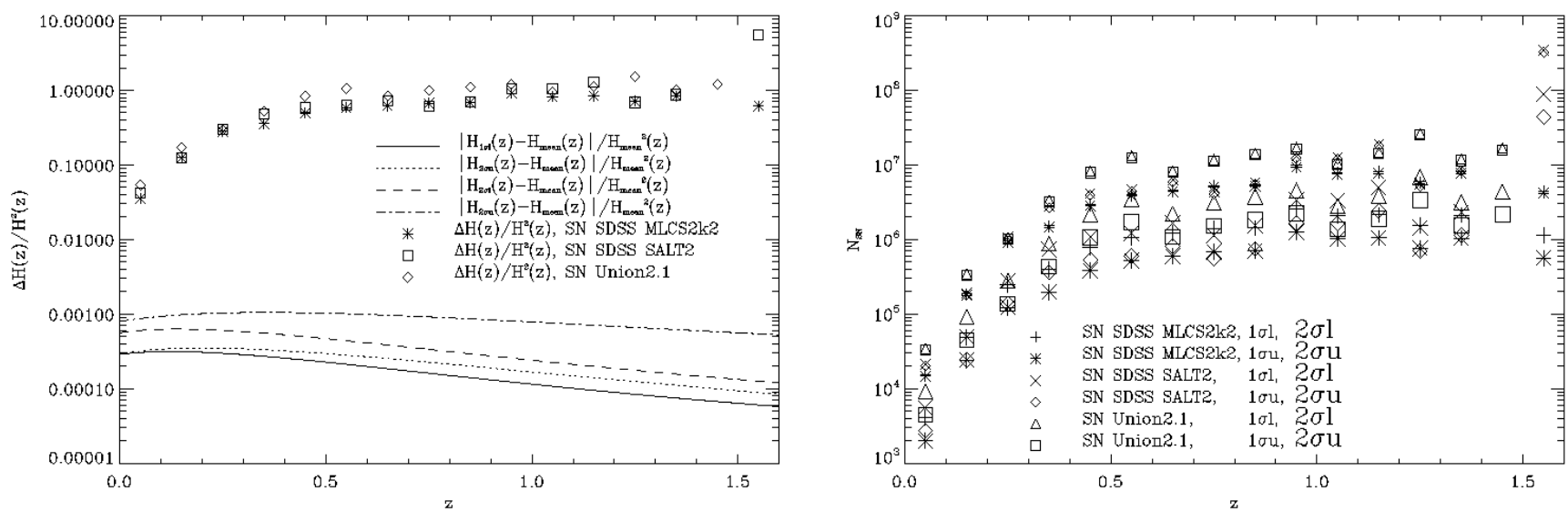

Fig. 2. Left: the theoretical relative differences $\Delta H_{\text {model }}(z) / H^{2}(z) \equiv\left|H_{1(2) \sigma}(z)-H_{\text {mean }}(z)\right| / H_{\text {mean }}^{2}(z)$ (for upper and lower limits) compared to $\Delta H(z) / H^{2}(z)$ from Supernovae compilations. Right: the minimal number of Supernovae that is necessary for distinguishing the models in left panel if the uncertainties of Supernovae magnitudes are the same as in the compilation from legend
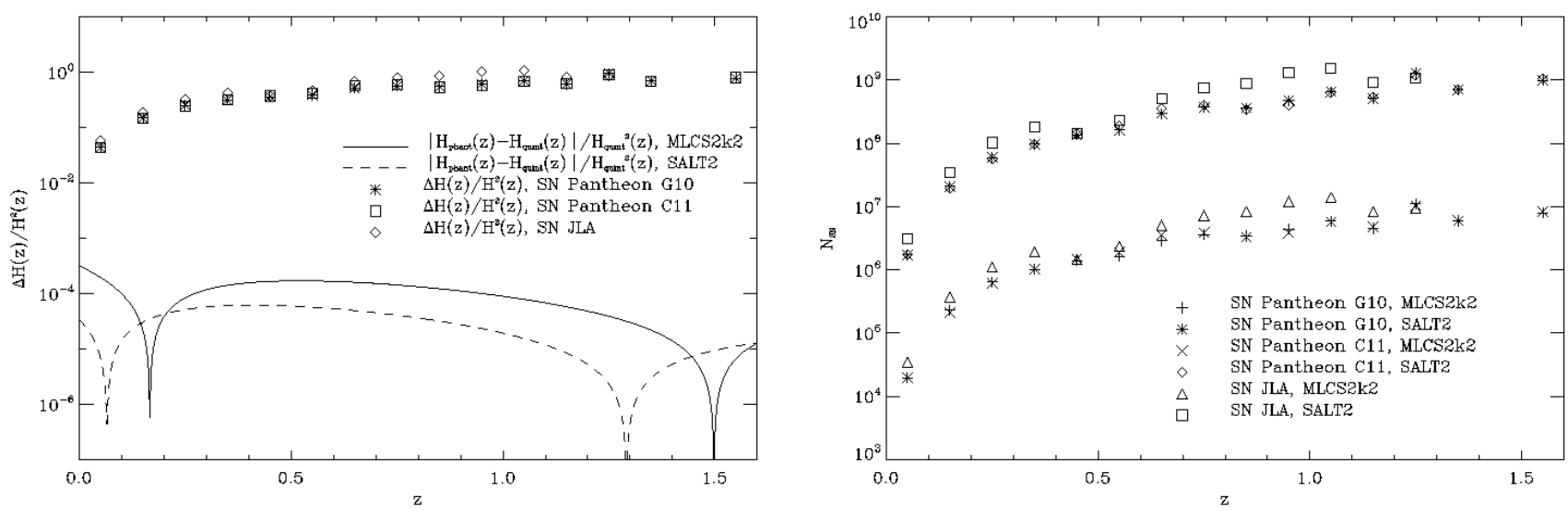

Fig. 3. Left: the theoretical relative differences $\Delta H_{\text {model }}(z) / H^{2}(z) \equiv\left|H_{\text {phant }}(z)-H_{\text {quint }}(z)\right| / H_{\text {quint }}{ }^{2}(z)$ compared to $\Delta H(z) / H^{2}(z)$ from Supernovae compilations. Right: the minimal number of Supernovae that is necessary

for distinguishing the models in left panel if the uncertainties of Supernovae magnitudes are the same as in the compilation from legend. After a comma we quote the data (type of Supernovae light curve fitting) used to estimate the best-fit parameters for the pair of compared models
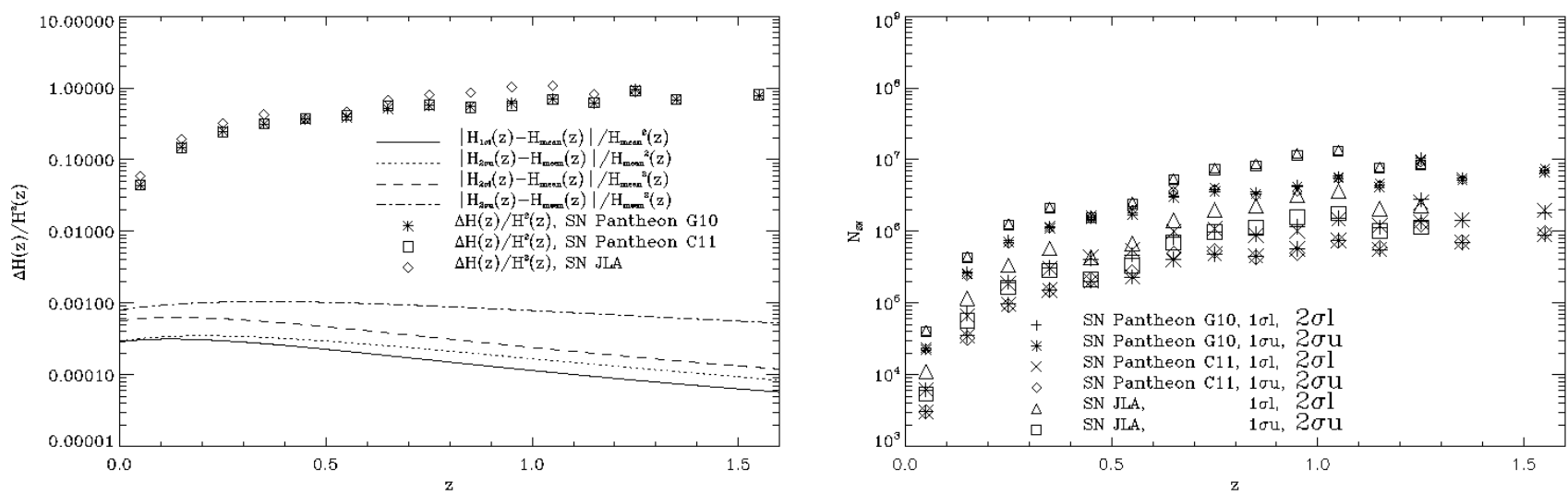

Fig. 4. Left: the theoretical relative differences $\Delta H_{\text {model }}(z) / H^{2}(z) \equiv\left|H_{1(2) \sigma}(z)-H_{\text {mean }}(z)\right| / H_{\text {mean }}{ }^{2}(z)$ (for upper and lower limits) compared to $\Delta H(z) / H^{2}(z)$ from Supernovae compilations. Right: the minimal number of Supernovae that is necessary for distinguishing the models in left panel if the uncertainties of Supernovae magnitudes are the same as in the compilation from legend

Acknowledgements. This work has been supported in part by the Department of target training of Taras Shevchenko National University of Kyiv under National Academy of Sciences of Ukraine (project $6 \Phi$ ). Author acknowledges the usage of CosmoMC package. 
References

[1] B. Javanmardi, Probing the Isotropy of Cosmic Acceleration Traced By Type la Supernovae / B. Javanmardi, C. Porciani, P. Kroupa, J. PflammAltenburg // Astrophys. J. 810, 47 (2015)

[2] U. Andrade, Isotropy of low redshift type la supernovae: A Bayesian analysis / U. Andrade, C.A.P. Bengaly, J.S. Alcaniz, B. Santos // Phys. Rev. D 97, $083518(2018)$

[3] C. Bonvin, Dipole of the Luminosity Distance: A Direct Measure of H(z) / C. Bonvin, R. Durrer, M. Kunz // Phys. Rev. Lett. 96, 191302 (2006).

[4] C. Bonvin, Fluctuations of the luminosity distance / C. Bonvin, R. Durrer, A. Gasparini // Phys. Rev. D 73, 023523 (2006).

[5] B. Novosyadlyj, Quintessence versus phantom dark energy: the arbitrating power of current and future observations / B. Novosyadlyj, O. Sergijenko, R. Durrer, V. Pelykh // J. Cosmol. Astropart. Phys. 06, 042 (2013).

[6] B. Novosyadlyj, Distinguishability of scalar field models of dark energy with time variable equation of state parameter / B. Novosyadlyj, O. Sergijenko, S. Apunevych // J. Phys. Stud. 15, 1901 (2011).

[7] O. Sergijenko, Scalar field as dark energy accelerating expansion of the Universe / O. Sergijenko, B. Novosyadlyj // Kin. Phys. Cel. Bod. 24, p. 259-270 (2008).

[8] A. Lewis, Cosmological parameters from CMB and other data: a Monte Carlo approach / A. Lewis, S. Bridle // Phys. Rev. D 66, 103511 (2002).

[9] N. Jarosik, Seven-year Wilkinson Microwave Anisotropy Probe (WMAP) observations: sky maps, systematic errors and basic results / N. Jarosik,

C.L. Bennett, J. Dunkley et.al. // Astrophys. J. Suppl. 192, 14 (2011).

[10] E. Komatsu, Seven-year Wilkinson Microwave Anisotropy Probe (WMAP) observations: cosmological interpretation / E. Komatsu, K.M. Smith, J. Dunkley et.al. // Astrophys. J. Suppl. 192, 18 (2011).

[11] D. Larson, Seven-year Wilkinson Microwave Anisotropy Probe (WMAP) observations: power spectra and WMAP-derived parameters / D. Larson, J. Dunkley, G. Hinshaw et. al. // Astrophys. J. Suppl. 192, 16 (2011).

[12] W.J. Percival, Baryon acoustic oscillations in the Sloan Digital Sky Survey Data Release 7 galaxy sample / W.J. Percival, B.A. Reid, D.J. Eisenstein et al. // Mon. Not. Roy. Astron. Soc. 401, 2148 (2010).

[13] A.G. Riess, A Redetermination of the Hubble constant with the Hubble Space Telescope from a differential distance ladder / A.G. Riess, L. Macri, S. Casertano et al. // Astrophys. J. 699, 539 (2009).

[14] G. Steigman, Primordial nucleosynthesis in the precision cosmology era / G. Steigman // Ann. Rev. Nucl. Part. Phys. 57, 463 (2007).

[15] E.L. Wright, Constraints on dark energy from supernovae, gamma ray bursts, acoustic oscillations, nucleosynthesis and large scale structure and the Hubble constant / E.L. Wright // Astrophys. J. 664, 633 (2007).

[16] R. Kessler, First-year Sloan Digital Sky Survey-II (SDSS-II) supernova results: Hubble diagram and cosmological parameters / R. Kessler, A.C. Becker, D. Cinabro et al. // Astrophys. J. Suppl. 185, 32 (2009).

[17] J. Guy, SALT2: using distant supernovae to improve the use of type la supernovae as distance indicators / J. Guy, P. Astier, S. Baumont et al. // Astron. Astrophys. 466, 11 (2007).

[18] S. Jha, Improved distances to type la supernovae with multicolor light curve shapes: MLCS2K2 / S. Jha, A.G. Riess, R.P. Kirshner // Astrophys. J. 659, 122 (2007).

[19] Planck Collaboration, Planck 2015 results. XI. CMB power spectra, likelihoods, and robustness of parameters / Planck Collaboration // Astron. Astrophys. 594, A11 (2016)

[20] Keck Array and BICEP2 Collaborations, BICEP2 / Keck Array VI: Improved Constraints On Cosmology and Foregrounds When Adding 95 GHz Data From Keck Array / Keck Array and BICEP2 Collaborations // Phys. Rev. Lett. 116, 031302 (2016).

[21] D. Parkinson, The WiggleZ dark energy survey: final data release and cosmological results / D. Parkinson et al. // Phys. Rev. D 86, 103518 (2012). [22] M. Betoule, Improved cosmological constraints from a joint analysis of the SDSS-II and SNLS supernova samples / M. Betoule et al. // Astron. Astrophys. 568, A22 (2014).

[23] G. Efstathiou, Ho revisited / G. Efstathiou // Mon. Not. Roy. Astron. Soc. 440, 1138 (2014)

[24] N. Suzuki, The Hubble space telescope cluster supernova survey: V. Improving the dark energy constraints above $z>1$ and building an early-typehosted supernova sample / N. Suzuki, D. Rubin, C. Lidman et al. // Astrophys. J. 746, 85 (2012).

[25] D.M. Scolnic, The Complete Light-curve Sample of Spectroscopically Confirmed SNe la from Pan-STARRS1 and Cosmological Constraints from the Combined Pantheon Sample / D.M. Scolnic, D.O. Jones, A. Rest et al. // Astrophys. J. 859, 101 (2018).

[26] M. Tanabashi, Review of Particle Physics / M. Tanabashi et al. (Particle Data Group) // Phys. Rev. D 98, 030001 (2018)

Надійшла до редколегії 07.11.18

О. Сергієнко, канд. фіз.-мат. наук,

Астрономічна обсерваторія

Київського національного університету імені Тараса Шевченка

\section{ДИПОЛЬ ВІДСТАНІ ЗА СВІТНІСТЮ ЯК ТЕСТ ДЛЯ МОДЕЛЕЙ ТЕМНОÏ ЕНЕРГІЇ}

Зәідно з даними космічної обсерваторії Планк темна енергія в сучасну епоху є близькою до космологічної сталої. Це ускладнює виявлення зміни параметра рівняння стану темної енергії з часом і розрізнення моделей темної енергії. Надійність визначення залежноcmi w(z) сутmєво зросте, якщо безпосередньо виміряти залежність Н(z) замість (чи разом з) відстаней за світністю чи кутовим діаметром, оскільки результати числового диференціювання сучасних спостережуваних даних є неточними. Залежність параметра Габбла від червоного зміщення можна визначити безпосередньо з диполя відстані за світністю до наднових типу Іа. Проаналізовано можливість використання даних щодо диполя відстані за світністю, отриманих із компіляцій наднових типу la SDSS, Unіоп2.1, JLA та Pantheon, для розрізнення моделей темної енераї. Установлено, що точність визначення відстаней і кількість наднових у цих компіляціях недостатні для використання залежності параметра Габбла від червоного зміщення, отриманої безпосередньо з диполя відстані за світністю, для розрізнення моделей скалярно-польової темної енергії з баротропним рівнянням стану. На червоних зміщеннях $0<z<0.1$, де чутливість такого космологічного тесту найвища, кількість наднових, необхідна для відрізнення моделі із середніми значеннями параметрів від моделі зі значеннями параметрів на межах $2 \sigma$ довірчого діапазону, перевищує кількість усіх наднових у найповнішій на сьогодні компіляції Рапtheоn не менше ніж у 1.9 раза, якщо похибки є лише статистичними, і не менше ніж у 2.9 раза за наявності систематичних похибок. Ппя практичного використання в майбутньому даних щодо диполя відстані за світністю необхідно як збільшувати кількість наднових у вказаному діапазоні червоних зміщень, так і покращувати точність фітування кривих блиску наднових типу lа та контроль систематики.

Ключові слова: темна енергія, наднові типу Іа, космологічні параметри.

О. Сергиенко, канд. физ.-мат. наук,

Астрономическая обсерватория

Киевского национального университета имени Тараса Шевченко

\section{ДИПОЛЬ РАССТОЯНИЯ ПО СВЕТИМОСТИ КАК ТЕСТ ДЛЯ МОДЕЛЕЙ ТЕМНОЙ ЭНЕРГИИ}

Согласно данным космической обсерватории Планк темная энергия в современную эпоху близка к космологической постоянной. Это затрудняет обнаружение изменения параметра уравнения состояния темной энергии со временем и различия моделей темной энергии. Надежность определения зависимости w(z) существенно возрастет, если непосредственно измерить зависимость Н(z) вместо (или вместе с) расстояний по светимости или угловому диаметру, поскольку результаты численного дифференцирования современных наблюдаемых данных являются неточными. Зависимость параметра Хаббла от красного смещения можно определить напрямую из диполя расстоянии по светимости сверхновых типа 1а. Проанализирована возможность использования данных по диполю расстояния по светимости, полученных из компиляций сверхновых типа 1a SDSS, Union2.1, JLA и Pantheon, для различения моделей темной энергии. Установлено, что точность определения расстояний и количество сверхновых в этих компиляциях недостаточны для использования зависимости параметра Хаббла от красного смещения, полученной напрямую из диполя расстояния по светимости, для различения 
моделей скалярно-полевой темной энергии с баротропным уравнением состояния. На красных смещениях $0<z<0.1$, где чувствительность такого космологического теста является высокой, количество сверхновых, необходимое для отличения модели со средними значениями параметров от модели со значениями параметров на границах $2 \sigma$ доверительного диапазона, превышает количество всех сверхновых в самой полной на сегодня компиляци Pantheоn не меньше чем в 1.9 раза, если погрешности являются только статистическими, и не менее чем в 2.9 раза при наличии систематических погрешностей. Для практического использования в будущем данных по диполям расстояний по светимости необходимо как увеличивать количество сверхновых в указанном диапазоне красных смещений, так и улучшать точность подгонки кривых блеска сверхновых типа 1а и контроль систематики.

Ключевые слова: темная энергия, сверхновые типа 1а, космологические параметры

Удк 524.1-52, 524.1-65

В. Войцеховський, асп., Б. Гнатик, д-р фіз.-мат. наук, проф., Ю. Кудря, канд. фіз.-мат. наук, старш. наук. співроб., Київський національний університет імені Тараса Шевченка, Київ

\section{ПРИСКОРЕННЯ ТА ПОШИРЕННЯ КОСМІЧНИХ ПРОМЕНІВ НАДВИСОКИХ ЕНЕРГІЙ У ЛОКАЛЬНОМУ ВСЕСВІTІ}

Розподіл речовини в Локальному Всесвіті (до 100 Мпк), особливо в районі надскупчення Діви ( 20 Мпк), дуже неоднорідний і включає всі елементи великомасштабної структури: галактики та їхні скупчення, надскупчення, філаменти, шари та пустоти (войди). Очікується, що розподіл позагалактичного магнітного поля (ПГМП) відповідає розподілу густини баріонної речовини. Космічні промені надвисоких енергій (КПНВЕ) з позагалактичних джерел зазнають суттєвих відхилень у ПГМП, утруднюючи пошук їхніх джерел. Крім того, потік ядерного компонента КПНВЕ послаблюється внаслідок фотодезінтеграції ядер при взаємодії з фоновим мікрохвильовим та інфрачервоним випромінюванням. У роботі оцінено вплив цих факторів на поширення КПНВЕ від джерел у Локальному Всесвіті, зокрема досліджено довжину вільного пробігу та магнітне відхилення ядер $\mathrm{H}(\mathrm{p})$, He, O, Si та Fe. Для потенційних джерел КПНВЕ в Локальному Всесвіті оцінено типи та енергії ядер, які можуть досягти Землі й водночас зберегти зв'язок напрямків прибуття з положенням джерела в межах 1рад.

Ключові слова: великомасштабна структура, Локальний Всесвіт, міжеалактичні магнітні поля, космічні промені надвисоких енергій, активні ядра галактик, галактики зі спалахом зореутворення.

Вступ. Космічні промені надвисоких енергій (КПНВЕ) - потоки високоенергетичних частинок з енергіями понад $10^{18} \mathrm{eB}$, що суттєво перевищують можливості земних прискорювачів, є винятково важливим джерелом інформації про фрізику фундаментальних взаємодій за межами стандартної моделі, однак досі невідомі їхні астрофізичні джерела та механізми прискорення [1, 3, 14]. У рамках електромагнітного прискорення заряджених частинок вимоги до розмірів областей прискорення та до величини електромагнітних полів виконуються в ряді галактичних і позагалактичних астрофрізичних джерел: у магнітосферах молодих мілісекундних магнетарів (у нашій Галактиці та в галактиках з активним зореутворенням (ГАЗО)), у релятивістських струменях космологічних гамма-спалахів і активних ядер галактик (АЯГ) [4, 14]. Спостережувана ізотропія потоку КПНВЕ свідчить про домінування позагалактичного компонента КПНВЕ та суттєве відхилення траєкторій КПНВЕ в міжгалактичних магнітних полях (МГМП) аж до дифузійного режиму їх поширення, коли відстань до їх джерел значно перевищує пробіг (масштаб розсіяння) КПНВЕ у МГМП [7]. Однак для космічних променів гранично високих енергій (КПГВЕ, E>5·1019 eB), що знаходяться на вершині енергетичного спектра космічних променів (максимальна енергія задетектованих космічних променів дорівнює $3 \cdot 10^{20} \mathrm{eB}$ ), i для космологічно близьких - у Локальному Всесвіті (ЛВ, до 100 Мпк) - джерел можна очікувати, що їх рух у МГПМ не встигне вийти на дифузійний режим, а відбуватиметься в т. зв. балістичному режимі, коли відхилення траєкторій КПГВЕ у МГМП будуть не надто великими й напрямки їх приходу на небесній сфері будуть корелювати з положеннями джерел у межах 1 рад $\left(\sim 57^{\circ}\right)$. Тому найбільш перспективним напрямом пошуку джерел КПНВЕ $є$ пошук кореляцій напрямків приходу КПГВЕ з потенційними позагалактичними джерелами ЛВ.

Розподіл речовини в Локальному Всесвіті, зокрема в районі надскупчення Діви (НСД, 20 Мрк), сильно неоднорідний і включає всі елементи великомасштабної структури: галактики та їхні скупчення, надскупчення, фріламенти й шари (зокрема Локальний філамент, що включає Локальний шар, до якого належить Місцева група), порожнини войди $[6,8,13,15,16]$. Розподіл потенційних джерел КПНВЕ - АЯГ, ГАЗО та розподіл магнітних полів у Локальному Всесвіті мають відстежувати розподіл баріонної матерії, у якому домінують Великий Атрактор (ВА, 80 Мрк), надскупчення Персея - Риб (НСПР, 70 Мрк) та надскупчення Діви [16, 20, 21]. Для визначення перспектив детектування КПГВЕ від потенційних джерел у ЛВ у нашій роботі ми оцінюємо характеристики ядер (енергія, заряд), які можуть досягти Землі і водночас зберегти зв'язок напрямків прибуття з позицією джерела в межах 1 рад.

Великомасштабна структура Локального Всесвіту. Локальний Всесвіт - область 100 Мпк навколо нашої Галактики - приблизно вдвічі перевищує за розміром середню відстань між скупченнями галактик - найбільшими гравітаційно пов'язаними структурами у Всесвіті, тому містить усі типові елементи великомасштабної структури Всесвіту. На його найменших масштабах наша Галактика й подібна до неї галактика М31 (Туманність Андромеди) на відстані 770 кпк разом з кількома десятками карликових галактик утворюють Місцеву групу галактик. Разом 3 подібними групами галактик Центавр A/M83 ( 4Мпк) і M81 ( 3.6 Мпк, включає галактики M81 і M82) і деякими іншими Місцева група входить у Локальний шар - млинцеподібну концентрацію галактик радіусом 5 Мпк завтовшки 1.5 Мпк $[6,13,15,19]$. Локальний шар є частиною (потовщенням) Локального філаменту - циліндричної області (радіус 2 Мпк) підвищеної концентрації галактик, що тягнеться від скупчення Піч до скупчення Діви (на відстані 16.5 Мпк від МГ) і вливається (уздовж Локального фріламенту існує реальний потік плазми міжгалактичного середовища) у більш потужний фріламент, який включає скупчення Діви й поєднує дві найбільші концентрації матерії в Локальному Всесвіті надскупчення Великий Атрактор (на відстані 80 Мпк від МГ) та надскупчення Персея - Риб (70 Мпк від МГ). Скупчення галактик Діви складає при цьому центральну частину надскупчення Діви (радіус 20 Мпк), на периферії якого знаходиться МГ (рис. 1) [8, 16, 20, 21]. 